\title{
THE INSCRIPTIONS OF THE TARTARUS PANEL AND THE 1833 FERCHER-SURVEY, POSTOJNSKA JAMA
}

\section{NAPISI NA STENI TARTARJA IN FERCHERJEVE MERITVE POSTOJNSKE JAME LETA 1833}

S. KEMPE ${ }^{1}$

${ }^{1}$ Institute for Applied Geosciences, University of Technology Darmstadt, Schnittspahnstr. 9, D-64287 Darmstadt, Germany, email: kempe@geo.tu-darmstadt.de; 


\section{Abstract}

UDC: 551.44(497.4 Postojna) (091)

\section{S. Kempe: The Inscriptions of the Tartarus Panel and the 1833 Fercher-survey, Postojnska jama}

The history of the discovery of the main parts of Postojnska jama that began in 1818 is not well documented. The article reports about the most interesting inscriptions of the "Idrianer" left on February $7^{\text {th }}, 1833$, including Johann Fercher, Aloys Urbas, Valentin Tracha, and Johann Wruss near the end of the then known main passage. Fercher was a mine supervisor at Idria. He conducted the first thorough survey of the cave, published first by Schaffenrath (1834). In the archives of Postojnska jama, kept by the Karst Research Institute ZRC SAZU in Postojna four documents survive illustrating the background of this survey. These documents, written in the $19^{\text {th }}$ century German Current handwriting are transcribed here for the first time. They not only list the participants of the survey (which also included surveyor Michael Glantschnigg and coachman Johann Leskovitz) but also report costs.

Key words: history, cave survey, Idrianer, Postojnska jama, Slovenia.

Izvleček

UDK: 551.44(497.4 Postojna) (091)

\section{S. Kempe: Napisi na steni Tartarja in Fercherjeve meritve Postojnske jame leta 1833}

Zgodovina odkrivanja glavnih delov Postojnske jame, ki so se začela 1818, še ni podrobno obdelana. Tukaj poročam o najzanimivejših podpisih v Tartarju blizu konca takrat znanega rova, kjer so se podpisali tako imenovani »Idrijci« 7. februarja 1833: Johann Fercher, Aloys Urbas, Valentin Tracha in Johann Wruss. Fercher je bil rudarski nadzornik v Idriji. Opravil je prve natančne meritve jame, ki jih je objavil Schaffenrath 1834. V arhivu Postojnske jame, ki ga hrani Inštitut za raziskovanje krasa ZRC SAZU, so ohranjeni štirje dokumenti, ki osvetljujejo ozadje teh meritev. Ti dokumenti, napisani v gotici in nemščini 19.stoletja, so tukaj prvič transkribirani. Ne vsebujejo le seznama merilcev (kjer sta omenjena tudi merilec Michael Glantschnigg in kočijaž Johann Leskovitz), ampak tudi pregled stroškov.

Ključne besede: zgodovina, meritev jame, Idrijci, Postojnska jama, Slovenija. 


\section{INTRODUCTION}

Postojnska Jama plays a central role in cave science history (e.g., Shaw, 1992). After the discovery of its inner parts initiated by the historical climb of the far side in the Velika Dvorana by Luka Čeč, in 1818 (Habe, 1968), many kilometres of passages were discovered within the next few years. These discoveries made the cave the longest documented cave system in the world for several decades until Mammoth Cave, Kentucky, took the lead as the longest cave on Earth, a record it still keeps. Apart from the early published reports (Volpi, 1821; Bronn, 1826; Hohenwart 1830, 1832a,b; Schaffenrath ,1834; Schmidl, 1854, 1858) and the pictures of Schaffenrath (published by Hohenwart, 1830, 1832a,b) (Kempe \& Henschel, 2004), inscriptions (Kempe, 2002; Kempe et al., 2004) are a most valuable source for the reconstruction of this interesting historic period. Here is discussed the Tartarus Panel, one of the most important inscription panels in Postojnska Jama that was created by the early explorers.

\section{THE TARTARUS PANEL}

The historic main passage of Postojnska jama describes a large curve, and ends towards the west after 850 Wiener Klafter (i.e. $1610 \mathrm{~m}$ ) from the entrance (Hitzinger, 1866). At the end it splits, the northern being dubbed the "Tartarus" or "Plutos Grotte", i.e. the netherworlds of the classic Greeks. The southern end leads to the "impassable basin". Here (Fig. 1) is found an inscription panel on the northern wall of the passage. It consists of two sections, separated by some flowstone (Fig. 2). The panel and its inscriptions are well preserved, being neither covered by new flowstone nor defaced by later visitors.

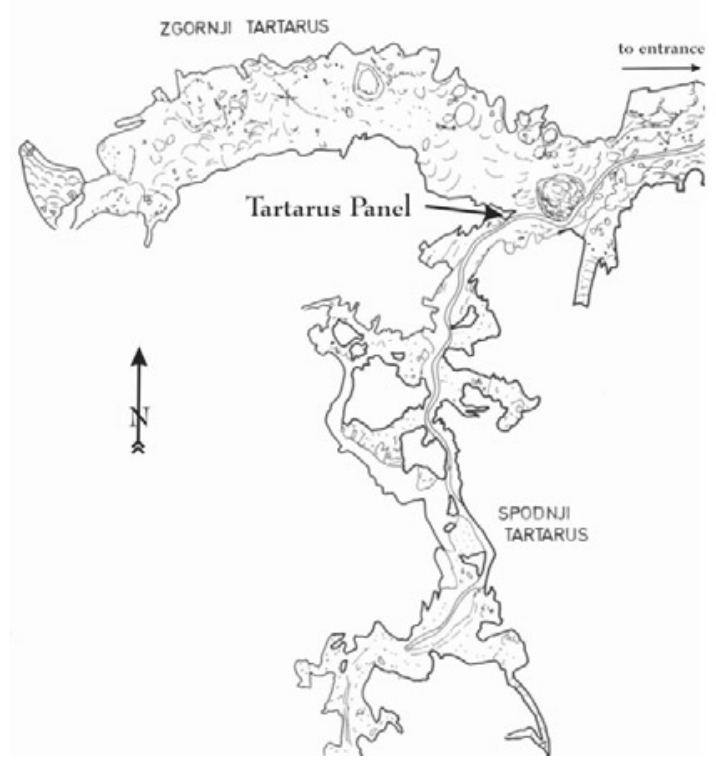

Fig. 1: The situation of the Tartarus Panel at the branch of the two Tartarus passages. 
Schaffenrath and Löwengreif were the first to inscribe their names at this place (Figs. 3, 4). On the right hand side Schaffenrath wrote "A. Schaffenrath, März 1825". This signature was written with a carbon pencil such as used for sketching. Schaffenrath's name is followed by a subscribed, but illegible abbreviation. A similar subscript is found under Schaffenrath's signature in Pisani Rov written also in 1825 (Kempe et al., 2004). In Pisani Rov it appears as if the subscript is a "SFF" as an artistic signature of "Schaffenrath". Schaffenrath also left his name in the Old Cave, dated 1829, but without a subscript.

On the left side of the panel Löwengreif, possibly written with the same carbon pencil which Schaffenrath used, left his signature reading "Löwengreif, zum Erstenmal den 22 März 1825" (i.e., "Löwengreif for the first time, March $22^{\text {nd }} 1825$ ") (Fig. 4). The date is not well legible and it may have been a different day. It appears as if Löwengreif and Schaffenrath visited this spot together, each leaving his name to the right and left of the panel in a quite symmetrical composition. For Schaffenrath it was apparently not the first time he reached this remote place, but apparently Löwengreif ("for the first time") never had previously been in that far.

A short time after, also in 1825, three more names were left (Fig. 5): "Evža Kalan; Franz (?) Stepančič, Gospodaritsch". The name of Gospodaritsch also appears on the inscription panel in Pisani Rov in conjunction with both Schaffenrath's and Löwengreif's names dated also 1825. Neither the names of Gospodaritsch nor those of Kalan or Stepančič have yet been found in other documents (pers. com. M. Kranjc). Nevertheless it may be assumed that they were cave guides from Postojna.

Certainly the largest and best composed inscription on the panel is that of the Fercher surveying team. It is placed immediately under Schaffenrath's name, as if it wanted to illustrate its importance (Fig. 6). This inscription, written in pencil, has six lines and gives both a date and the names of the surveyors in the team. It is partly written in Current writing (German handwriting style in use in the early $19^{\text {th }}$ century) and in Latin letters. The first line reads: "Bey Aufnahme der Grote den 7. Februar 1833 ", i.e.: "During the survey of the Cave on February $7^{\text {th }}, 1833$ ". The word "bey" in modern German is spelled "bei". The word "Grote" is obviously misspelled for "Grotte" and the "7" apparently has been a "4" originally, as if the members of the party were not entirely sure about the day of the month. Below follow, in an orderly column, four names: "Johann Fercher, Urbas Aloys, Valentin Tracha, Johann Wruss". The reading of the first name of Wruss is unclear but from the document presented below, we know it should be "Johann". The double " $n$ " in "Johann" is indicated by a horizontal dash above the "n". Urbas listed his family name first, as was typical for Austrian and Bavarian usage. Fercher's name is preceded by the abbreviation for "Herr" (Mister) in Current writing (pers. comm. H. Süß). A quotation mark repeats the title for each of the team members. Fercher's name has a little bit more space inserted before the next name, suggesting that he was the team leader and that he was the one composing the panel. Behind and slightly below Urbas' name is another very small pencil mark which appears to be composed of three (?) capital letters, possibly "IHG". Below the names another word is found reading "Idrianer", i.e. "Idrians" meaning that the surveyors were employed by the mining company at Idrija. This usage of the word is similar to how today workers denote themselves as "Wolfsburger" when they work for Volkswagen or as "Rüsselsheimer" when they work for Opel/General Motors. This last word is underlined by an elaborate arrow, similar to the North arrow as placed on a survey map. The entire inscription is enclosed in a crude figure eight frame composed of a single pencil line. 
S.Kempe: The Inscriptions of the Tartarus Panel and the 1833 Fercher-survey, Postojnska jama

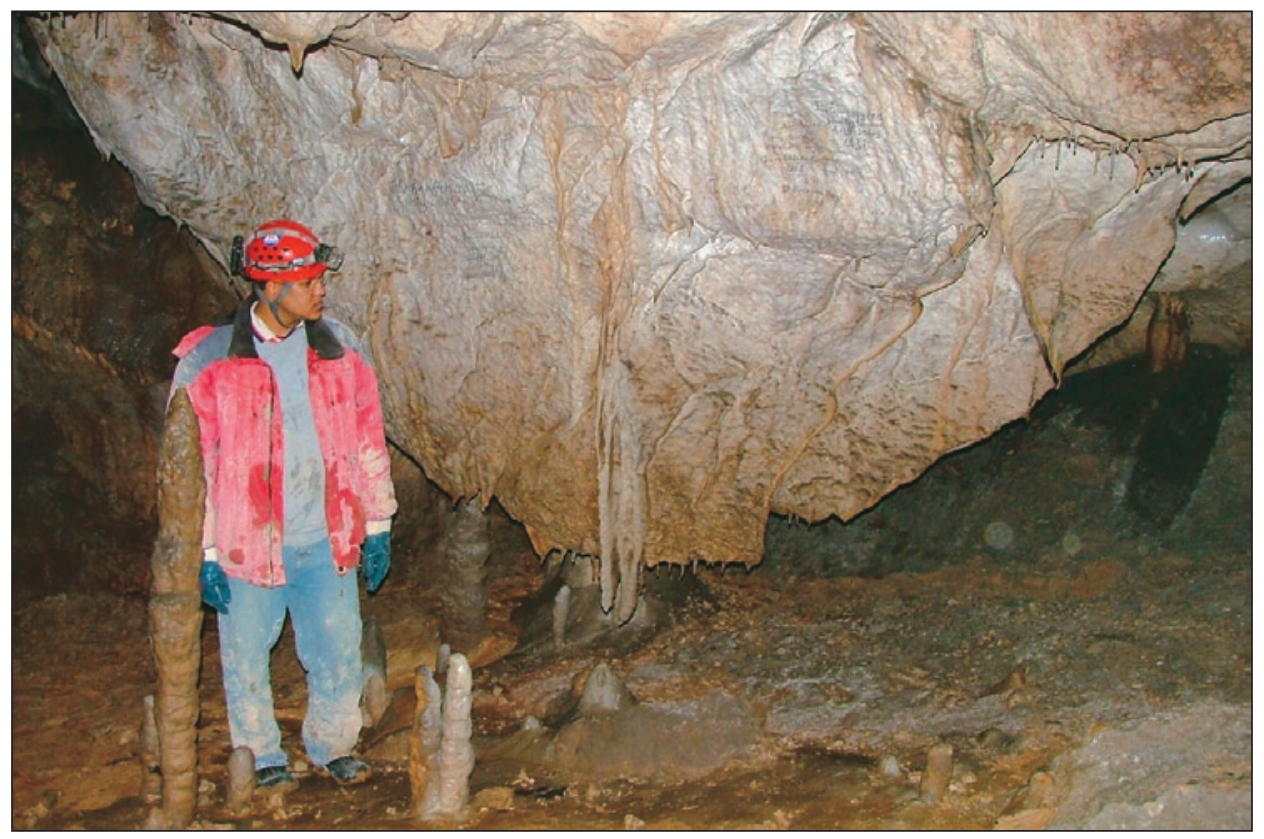

Fig. 2: The Tartarus Panel (Photo by author; for scale: Crisanto da Silva, Venezuela).

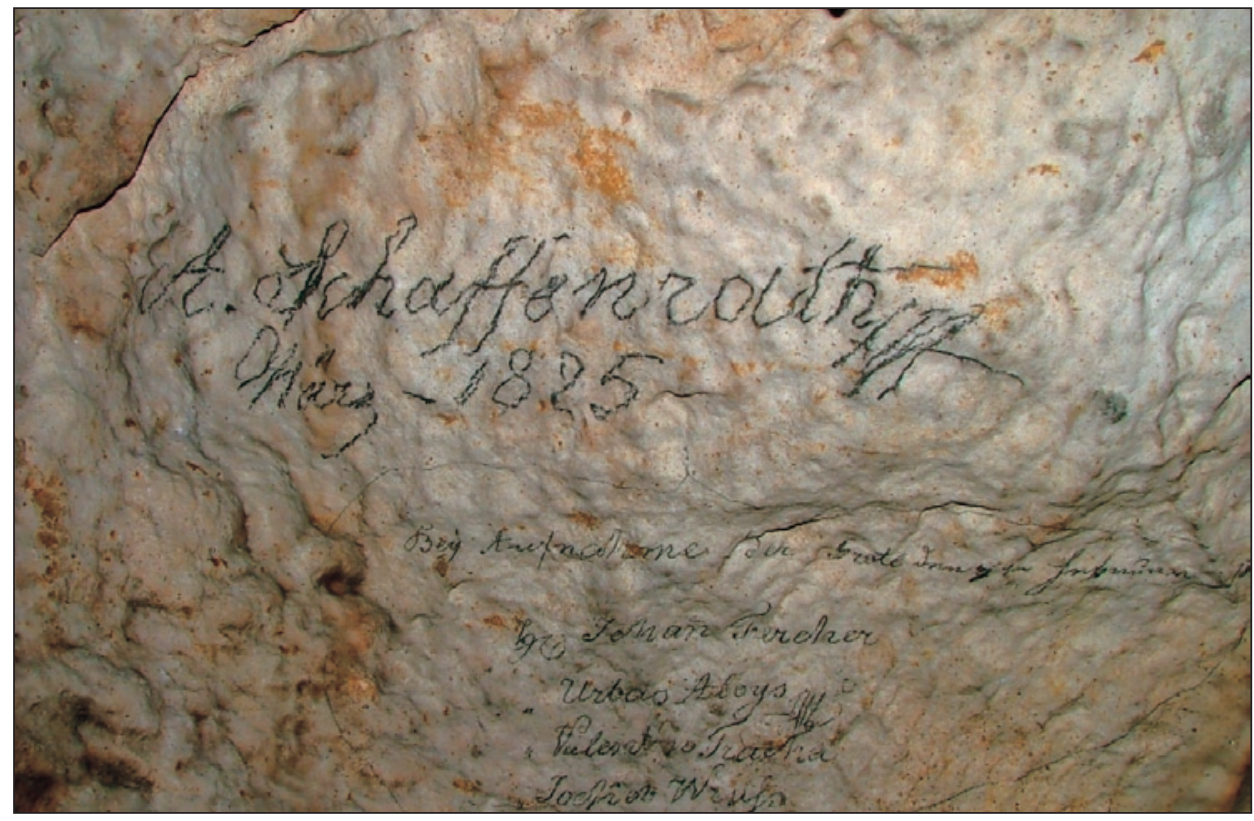

Fig. 3: Schaffenrath's inscription on the right side of the Tartarus Panel (Photo by author). 


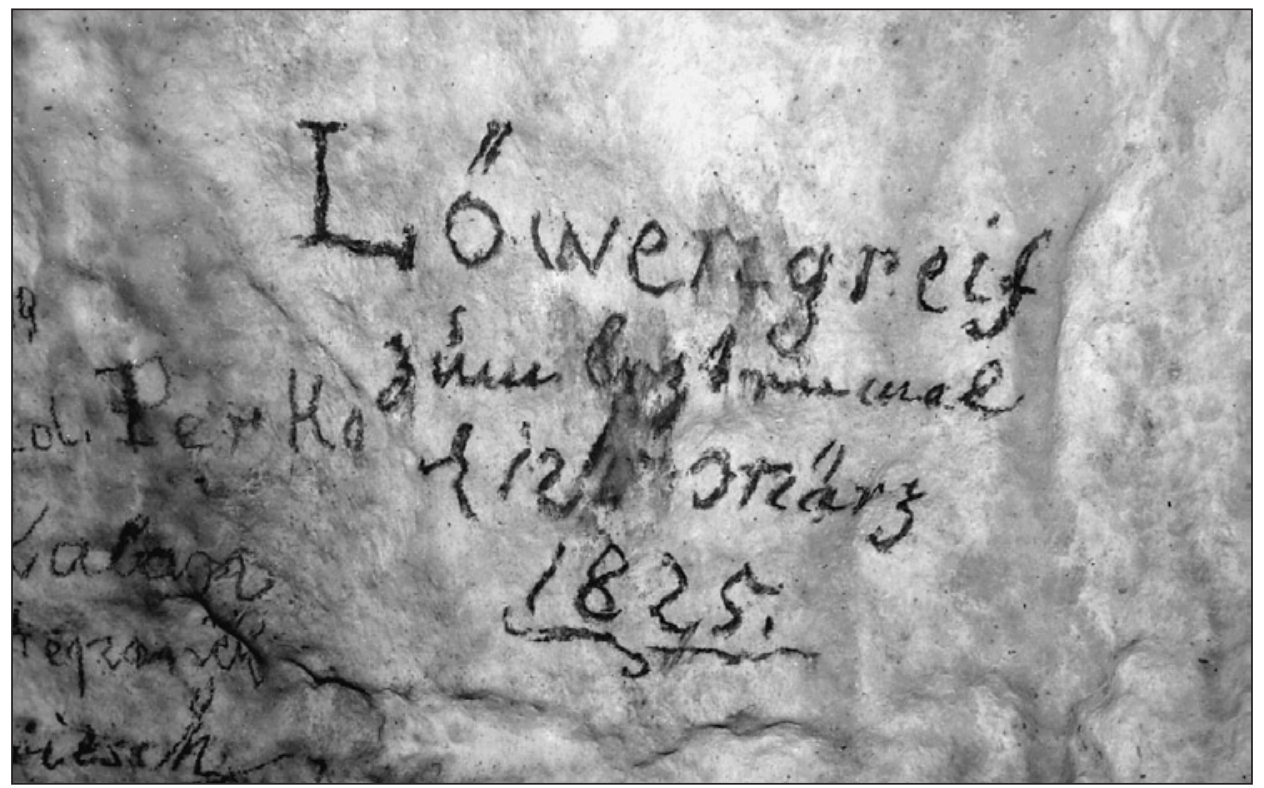

Fig. 4: Löwengreif's inscription on the left side of the Tartarus Panel (Photo by author).

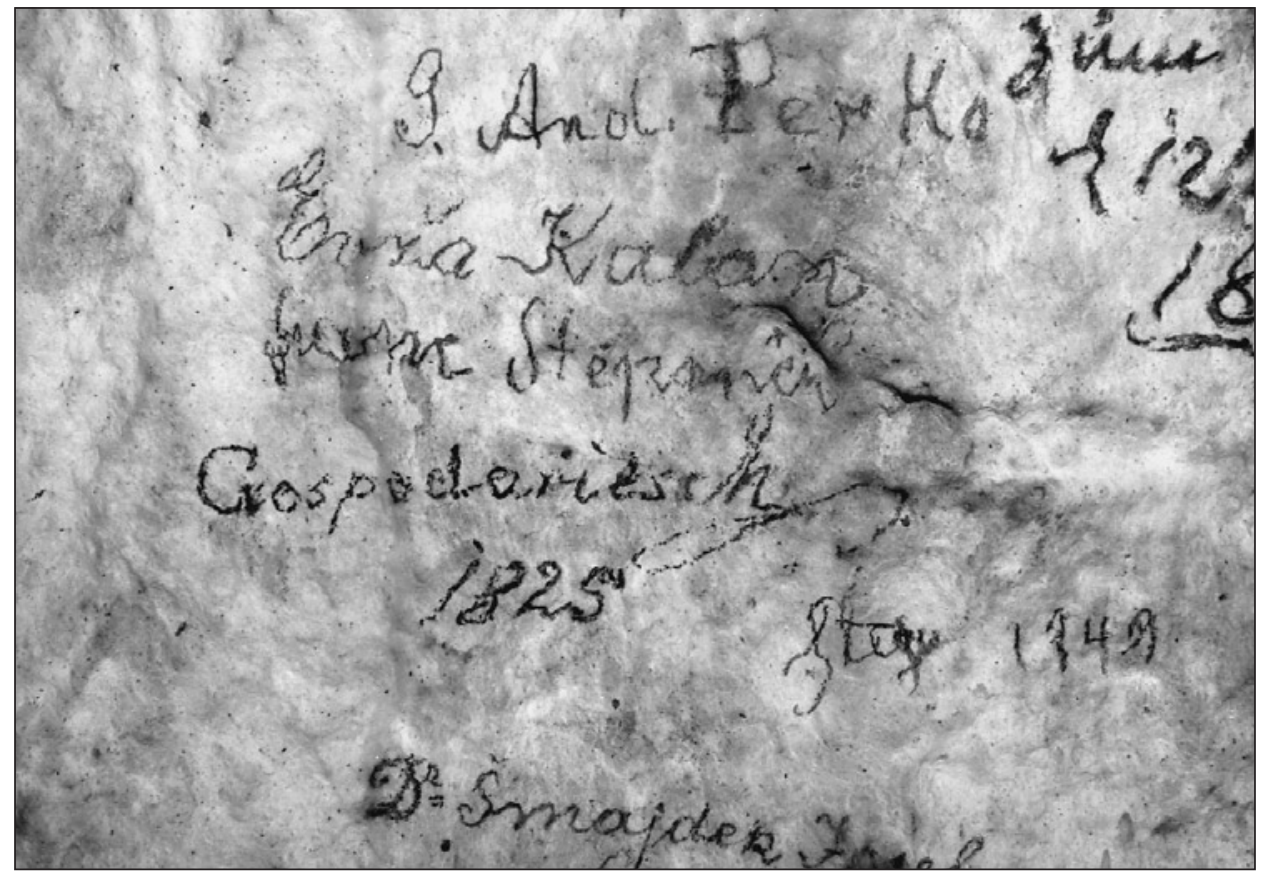

Fig. 5: Names of early cave guides on the Tartarus Panel (Photo by author). 
For more than 60 years, the Tartarus Panel was left unaltered. Then, in 1909, two more names were added: Those of J. And. Perko 12/5/1909 (Fig. 7) and of Dr. Josef Šmajdek 12.IV.1909 (Fig. 8). Since the dates differ only for the month, one may speculate that actually Perko and Šmajdek visited the Tartarus together and just erred when writing the dates. Ivan Andrej Perko was the long-time director of Postojnska Jama. His signature, "I.A. Perko 1892", is also present in Rov Brez Imena (Kempe et al., 2004). At that time he was sixteen years old, a year before he, his brother and others founded the student cavers club "Hades" in Triest. Nothing is known as yet about Šmajdek.

The next to sign the panel was a certain "Stegu" (Fig. 7). His name is also documented for Pisani Rov at the place where the path dips below a ceiling arch and turns around a large block. The date on the Tartarus Panel could either be read as 1948, but 1849 is also possible. If it is 1849, then the signature could be that of a certain Tomaž Stegu who is documented in 1858 as a "daily cashier" (selling also tickets for the cave) of the "Grottencommission" (pers. com. A. Kranjc).

\section{THE DOCUMENTS OF THE FERCHER SURVEY}

In searching for documents illuminating the background of the 1833 survey (Fig. 9) of the cave Mrs. M. Kranjc visited first the Idrija Mine Archive but without success. But then she uncovered four documents in the Postojnska Jama Archive (kept at the IZRK) of the year 1833 which concern the Fercher survey (these are the documents 429, 747, 986 and 57). They are Current script notes written in the German language. Transcripts of the documents into Latin script are given in the Appendix.

Document 429 is a note to the Cave Commission at Postojna written by acertian Prettmann "Bergrath" (i.e., Director of the Bureau of Mines) of the Idrija Mine on 22 ${ }^{\text {nd }}$ April 1833. It acknowledges the receipt (received on April $15^{\text {th }}$ as document 13 of the Grotto Commission) of 173 Gulden (abbreviated F for Florin), 32 Kreuzer for the travel expenses ("Reisespesen") of the survey team and submits the receipts ("Quittungen") signed by the individual participants in the survey. There follows the list of the recipients - including their professions, names and the amounts of expenses. This list is an independent confirmation of the reading of the names on the Tartarus Panel. From it we learn that Fercher was "Huttmann" or in modern German "Steiger", i.e. Supervisor of the miners at Idrija. He also received the biggest share of the expenses. Urbas was his assistant ("Gehülfe" or "Gehilfe" in modern German" receiving the second highest payment from those working in the cave. Wruss and Tracha were simple miners receiving the least reimbursements. Surprisingly the list in Document 429 contains two more names: those of the surveyor (in German "Markscheider") of Idrija, Michael Glantschnigg and of the coachman ("Fuhrmann") Johann Leskovitz. Both received a reimbursement higher than those of Urbas, Wruss and Tracha. It is clear that the coachman was not present in the cave, and that Glantschnigg's name was not included on the panel. This is confusing. Possibly Glantschnigg did not take part in the actual work in the cave but was instead responsible for reducing the data the others were collecting.

The next Document, No. 747, signed on July $11^{\text {th }} 1833$ also by Bergrath Prettmann, notifies the Cave Commission that Valentin Tracha obtained 50 pounds of explosives. The costs of 16 Gulden and 40 Kreuzer were to be paid by the Commission. This note suggests that the Cave Commission asked for some mining job to be done in the cave - the nature of which is not immediately apparent.

The third Document, 986, is addressed to the Grottenverwaltung. Verso (i.e. on the other side) it contains a statement signed by Johann Fercher on September $8^{\text {th }}$, 1833, directed to the K. K. 
"Bergamt" (Bureau of Mines) at Idrija. The Bergamt transmitted it in turn to the Grottenverwaltung. In this note Fercher refers to a letter labelled No. 52 from the Grottenverwaltung in which it apparently raised doubts with regard to the accuracy of the survey which Fercher supervised. The letter 52 is not preserved or has not yet been located. Fercher's response is difficult to read because his German grammar is lacking and because he tries (as usual during those times) to construct unnecessarily complicated sentences, sometimes finishing them without a proper verb. Furthermore his orthography is difficult to match with modern words in some instances. In order to help in reading the text, necessary additions are given in brackets. Also he misspelled some nouns with lower case letters which is - and was even then - incorrect in German.

First of all Fercher denies all charges against the accuracy ("Richtigkeit") of the survey ("vorgelegter Mappe") and of the attempted breakthrough ("Durchschlag"). He continues to explain that in a simple survey ("einfache Aufnahme") no drafter ("Vorzeichner") or surveyor ("Markscheider") can be held responsible ("gutstehen kann") for small differences. This is all the more so, because nobody expected that a connection between the two grottoes may exist. Also only the data of Urbas (i.e., Fercher's assistant) were used to construct the map. He continues that, during his last visit in the Adelsberger Grotte, he (der "Gehorsamste", i.e. the "most obedient") noticed that there is no doubt that the two passages come together. This must be true even if the shape of the two grottos seems to be shifted against each other and even if the distance might be somewhat longer. The next sentence is somewhat unclear in its meaning, but I suggest that he wants to say that the exact distance could be ascertained by starting a resurvey from the next fixed points. Then he says that even if the sound contact may be misleading ("Täuschung des Gehörs"), and that even if the present attempt ("gegenwärtiges Ansitzen") to gain the breakthrough may be pointing into the wrong direction that there is no doubt that the connection ("Löcherung") may be accomplished. He apparently even had attached a sketch map ("Croquis") that is not preserved.

In order to clarify the situation Fercher suggests a two step approach to the Bergamt. First the respective survey legs ("Züge") should be controlled in order to calculate the exact difference between the two endpoints. And then the workers could be contracted ("Geding") at about 50 Gulden per Klafter (one Wiener Klafter measuring 1.896m). This could be done without supervision, thus saving cost (,dabei die Aufsicht in Ersparung gebracht werden würde”).

In the final document (No. 57 G.V. written on the frontpage of Document 986.) the " $\mathrm{k} . \mathrm{k}$. Kreisingenieur" is asked to estimate the amount of rock removed by the workers and to state how much one miner might move during one shift. The signature is illigible. The "Kreisingenieur" must have been Aloys Schaffenrath, since he held the post around that time. The answer to this request apparently is not preserved.

\section{CONCLUSIONS}

The Tartarus Panel and the preserved documents relating to it shed light on the 1833 survey of Postojnska Jama (i.e. during reign of Emperor Franz I of Austria, who died in 1835). It was conducted by a team of miners from Idria lead by supervisor Johann Fercher and consisted of Aloys Urbas (assistant) and of the two miners Valentin Tracha and Johann Wruss. Urbas apparently was responsible for the survey of side passages. This can be concluded from Fercher's statement in the third document and from the fact that Urbas was the only one who signed the inscription column 


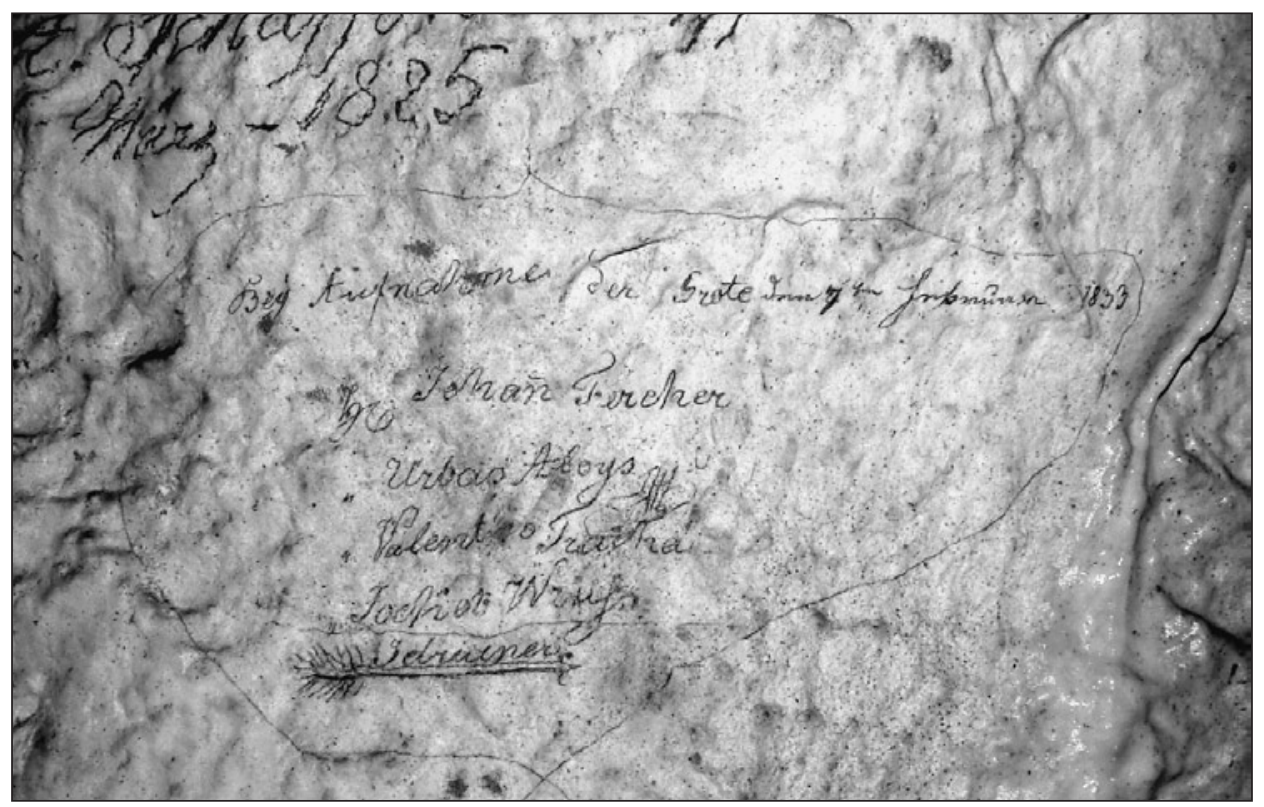

Fig. 6: Inscription of surveyor team from Idria (Photo by author).

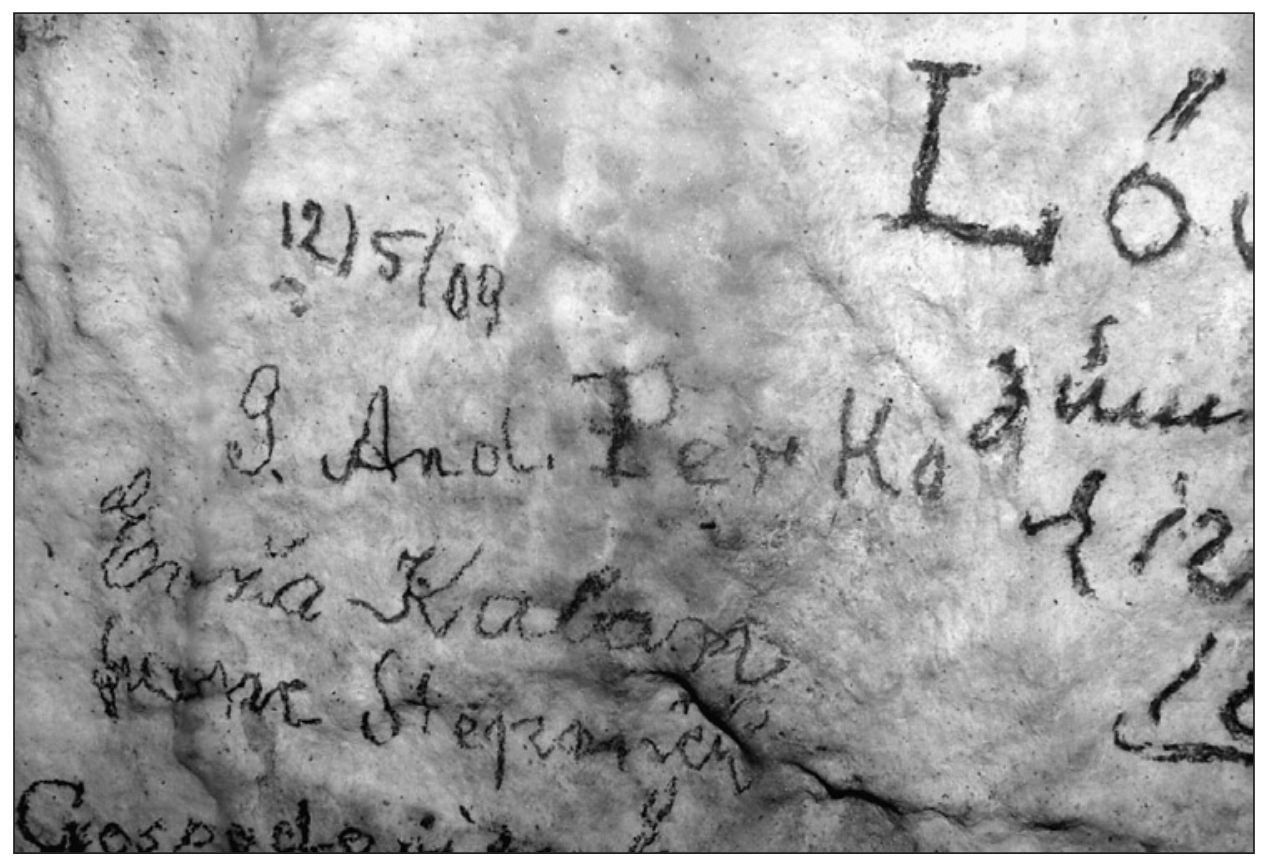

Fig. 7: Inscription of Iwan Perko on the Tartarus Panel (Photo by author). 
in Pisani Rov (Kempe et al., 2004). The team also consisted of the surveyor Michael Glantschnigg and of coachman Johann Leskovitz, both of whom are not documented in the cave. The survey was conducted in February 1833 and on February $7^{\text {th }}$ the team reached the Tartarus when they inscribed their names where Schaffenrath and Löwengreif had left theirs before.

Since these miners were employees of the mercury mine at Idrija, several letters must have been exchanged between the Grottenverwaltung and the Bergamt in Idrija before the actual survey in order to request the team and to negotiate the conditions of their reimbursement. These letters are either lost or have not yet been located.

Document 429, sent from the Bergamt to the Grottenverwaltung on April 22 ${ }^{\text {nd }}$, is the acknowledgement of receipt of payment. Therefore another letter by the Bergamt must have existed which claimed those costs. It is interesting to note that only travel expenses ("Reisespesen") were claimed, but no salary. A total of 173 Gulden 32 Kreuzer was paid to the participants of the survey. This amount is the first preserved cost assessment of a large cave survey world-wide. A search in the internet ( (C) bei Kopp Werner, 6060 Hall in Tirol) revealed that 1 Gulden in $1850=136$ Austrian Shillings (1992). Thus about $€ 1750$ were spent on the survey.

Up to this point, the Grottenverwaltung and the Bergamt seem to have been on good terms. What follows apparently is a completely different story. It is only partly illuminated by the next three documents. First the Bergamt, on July $11^{\text {th }}$, supplied the miner Tracha with 50 pounds of black powder (nitro-glycerine was invented in 1847) to do blasting in the cave. This in itself is not very conclusive, since the blasting could have been used anywhere in the cave to blast blocks or to level the ground. But Fercher's note of September $8^{\text {th }}$ tells us what was going on: Apparently the survey

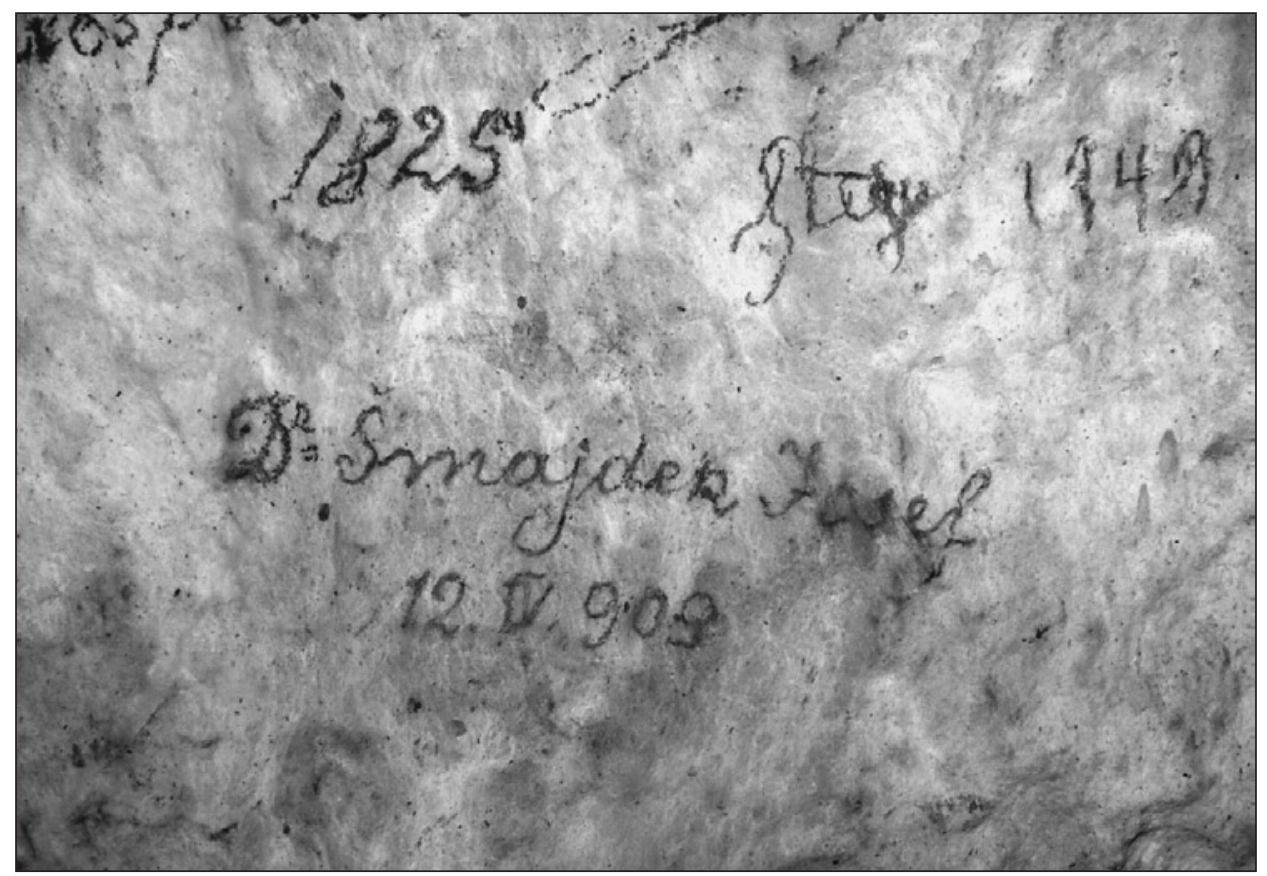

Fig. 8: Inscription of Dr. Šmajdek and Stegu on the Tartarus Panel (Photo by author). 


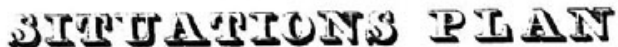

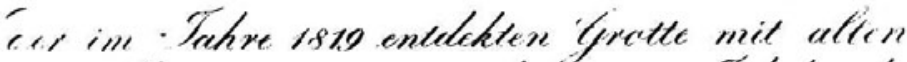

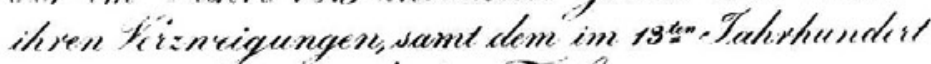
besuchteri sheile.

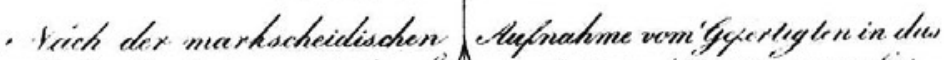

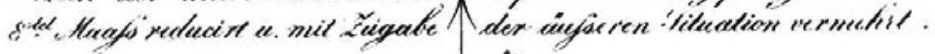

Erklärung.
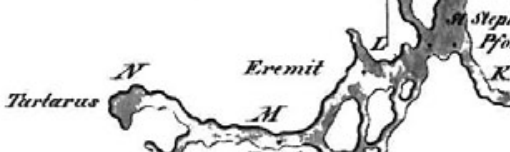

Exassin Gi.

Bropien.

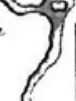

A. Eingeng in die Grolle

b. Whe alte brolle

C. Des erote \&.Monument

D Das sweite)

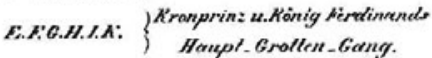

L. M A $Y$. Silen Gang zum Bafsin u. Therlarws.

a P. Erzherzog - Johenn - Grotte.

Q. A. Kngangbare Akiten Grotte.

5.7: Die beyder millelst eines Hotlens zu verbindenden Grollen.

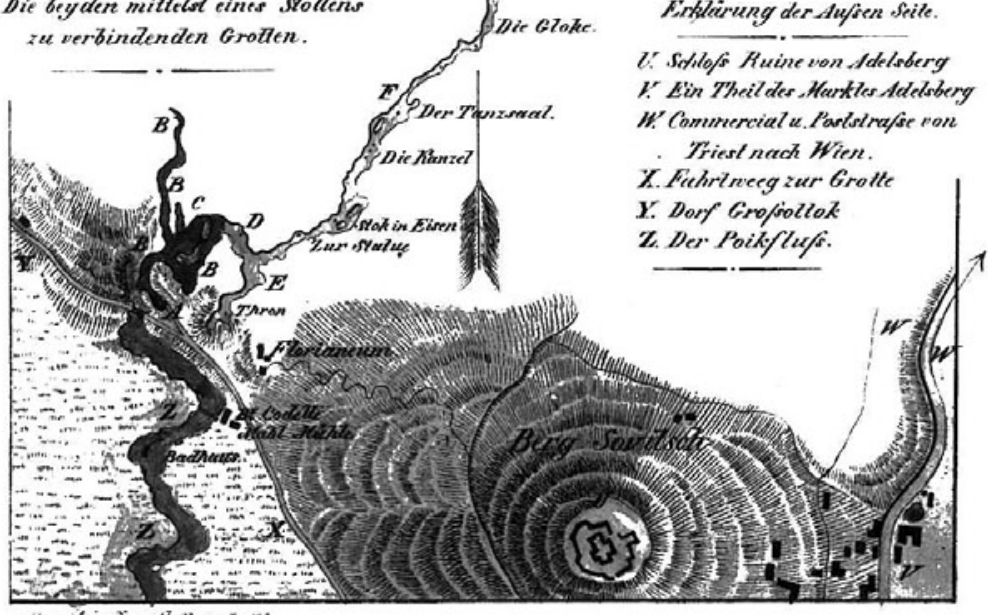

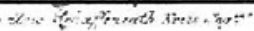

Fig. 9: The Fercher Survey of Postojnska jama as published by Schaffenrath (1834). 
had shown that one could connect two of the side passages easily. A look at the map (Fig. 9) shows, what probably was attempted: The Grottenverwaltung wanted to connect the two "Seitengrotten" at the "Grab" (i.e., the Grave) (ending at S) and at the Tropfbrunnen (i.e., the Dripwell) (ending in T). This would have allowed guides to lead visitors from the Tartarus back to the main passage much faster than by retracing their steps through the main passage. Schaffenrath in his own guide published in 1834 refers to this idea. Obviously it was assumed by the Grottenverwaltung that only a few metres needed to be removed and that this had failed. Then the Grottenverwaltung complained about this to the Bergamt, prompting Fercher's angry response. He suggested resurveying the presumed connection, and then offering a fixed contract to the miners to open the passage at a cost of 50 Gulden per Klafter. The final note, written at the end of October, apparently tries to confirm this estimate by asking Aloys Schaffenrath in his function as a county engineer to give an unbiased estimate ("unumwundenen Äußerung") of how much rock has already been removed and how much a miner may remove per daily shift.

Even though Schaffenrath (1834) wrote apodictically that the connection will be made with a "kunstmäßig angelegten Stollen" (i.e. an artificially made passage), the Grottenverwaltung apparently did not push the project any further until 1856. The reason for the resumed interest was the announced visit of Emperor Franz Josef and Empress Elisabeth which happened on March $11^{\text {th }} 1857$ (Shaw and Čuk, 2002). The breakthrough was accomplished very quickly in 1856 and was 6 Klafter and 3 Schuh long, (i.e. ca. $12 \mathrm{~m}$ ) and 6 x 6 Schuh wide (Hitzinger, 1866). The combined passage then became known as "Franz Josef und Elisabeth Grotte". It is just now being renovated, and is today known as Male Jama (i.e. Small Cave; Habe, 1986).

\section{ACKNOWLEDGEMENTS}

This paper could not have been written without the competent and kind help of Mrs. Maja Kranjc, the librarian of the Karst Research Institute at Postojna. Thanks are due also to Dr. Tadej Slabe Director of the Institute for his continued support. Dr. Stane Granda, Ljubljana, H. Süß, Linz, and K. Suckstorf, Geesthacht, helped with transcribing the Current writing. Stanislav Glažar guided us (S.K. plus his students) on October $14^{\text {th }}$ through the cave when the pictures of the Tartarus Panel were taken. Dr. M. S. Werner, Hilo, Hawaii, and Dr. S. Craven, South Africa, helped in editing. 


\section{REFERENCES}

Bronn, H.C. 1826: Briefe aus der Schweiz, Italien und Südfrankreich im Sommer 1824. - Heidelberg, 652 pp, 4 Lithographs.

Habe, F., 1968: Luka Čeč, odkritelj Postojnske jame.- 150 let Postojnske jame, 1818-1868, 9-17, Postojna.

Habe, F., 1986: The Postojna Caves. - Postojna, 82 pp., plates, 1 map.

Hitzinger, P., ca. 1866: Beschreibung der berühmten Adelsberger Grotte in Krain; nach der vom k.k. Kreis-Ingenier Alois Schaffenrath verfassten Beschreibung neuerlich bearbeitet und mit Zugabe einer Einleitung und einer Beschreibung der neuen Maria Anna-Grotte von P. Hitzinger, dann eines Situationsplanes der ganzen Grotte. - Maximilian Schäfer, Adelsberg, 32pp.

Hohenwart, F. Graf von, 1830, 1832a, 1832b: Wegweiser für die Wanderer in der berühmten Adelsberger und Kronprinz Ferdinands-Grotte bey Adelsberg in Krain; als Erklärung der von Herrn Aloys Schaffenrath, k.k. Kreis-Ingenieur in Adelsberg, gezeichneten Ansichten dieser Grotte. - Wien, J.P. Sollinger, 3 Vol., $16+9+14$ pp. und 21 copperplates (Reprint 1978: Šajn, S., ed.; Introduction: Habe, F. \& Šlenc, J.: Postojnska jama; 1. ed., Postojnska Jama THO; Postojna; 32 pp Introduction, folio).

Kempe, S., 2003: Die alten Inschriften der Adelsberger Grotte /Postojnska Jama. - Die Höhle, 54(2): 36-44.

Kempe, S. \& Henschel, H.-V., 2004: Alois Schaffenraths ,zerbrochene Pyramide“ (Postojnska jama), ein Zeuge glazialer Höhlenvereisung? - Mitt. Verb. dt. Höhlen- u. Karstforsch 50(3): 76-81.

Kempe, S., Bauer, I., Dirks, H., \& Henschel H.-V. (2004): Schaffenrath's Inscription Column in Pisani rov, Postojnska jama. - Acta carsologica, 33/2: 299-312.

Perko, G.A., 1929: Die Adelsberger Grotte in Wort und Bild. - Postumia (Postojna), Kgl. Grottenverwatung, $123 \mathrm{pp}, 2$ folded maps.

Schaffenrath, A., 1834: Beschreibung der berühmten Grotte bei Adelsberg in Krain. - I. Edlen v. Kleinmayr, Laibach, 32 pp., 2 Lithographs.

Schmidl, A., 1854: Die Grotten und Höhlen von Adelsberg, Lueg, Planina und Laas, Text and Atlas. - Wilhelm Braumüller, Wien, 316 pp, 15 Plates.

Schmidl, A., 1858: Wegweiser in die Adelsberger Grotte und die benachbarten Höhlen des Karstes. - 2. Aufl., C. Gerold's Sohn, Wien, 93 pp., 3 Lithogaphs.

Shaw, T.R., 1992: History of Cave Science, the Exploration and Study of Limestone Caves, to 1900. - $2^{\text {nd }}$ ed., Sydney Speleological Soc., Broadway, New South Wales, Australia, 338 pp.

Shaw, T., \& Čuk, A., 2002: Royal and other nobel visitors to Postojnska jama. - Acta Carsologica 31(1) (Suppl. 1): 106 pp.

Volpi, G. de, 1821: Über ein bey Adelsberg neuentdecktes Paläotherium. - Maldinische Schriften, Triest, 31 pp, 2 Plates. 


\section{APPENDIX}

The following texts have been transcribed from German Current handwriting. The German is very old-fashioned, enriched with expressions from mining language. It is not possible to translate these in a way reproducing the style of these notes. Moreover they are full of orthographic (compared to today's German) and grammatical mistakes. For an explanation of the contents and meaning please refer to the text of the paper.

\section{No. 429. An die löbliche Grottenverwaltungs Commission zu Adelsberg}

Note!

Nebst Bestätigung des Empfangs der, mit verehrter ${ }^{1}$ Note von $15^{\text {ten }}$ d. M. Zahl 13 G. V. ${ }^{2}$ eingesendeten 173 f. 32 kr. ${ }^{3}$ Reisespesen Vergüttung bey markscheiderischer Aufnahme der Adelsberger Grotte, werden die Quittungen der betreffenden Perzipienten, und zwar:

$\begin{array}{lllr}\text { Des } & \text { Marktscheiders } & \text { Michael Glantschnigg } & 32 \mathrm{f} .32 \mathrm{kr} . \\ " & \text { Huttmanns } & \text { Johann Fercher } & 65 \mathrm{f} . \quad-, \\ " & \text { Gehülfens } & \text { Aloys Urbas } & 24 \mathrm{f} . \quad-, \\ " & \text { Fuhrmanns } & \text { Johann Leskovitz } & 32 \mathrm{f} . \quad-, \\ " & \text { Bergmanns } & \text { Johann Wruss } & 10 \mathrm{f} . \quad-, \\ , & \text { dito } & \text { Val. Tracha } & 10 \mathrm{f} . \quad-, \\ & & \text { Summa } & 172 \mathrm{f} 32,\end{array}$

anmit ergebenst angeschlossen.

Kais. König. Bergamt Idria am 22. Aprill 1833

Prettmann Bergrath

[Reading of name not entirely certain, but same as in Note 747]

1 The first letter of this word is not a lower case „v“ but comparison with Note 747 makes certain that the word is ,verehrter" "honoured".

2 This abbreviation is not very clearly written, but comparison with the other documents and logic makes it certain that it stands for "G. V." "Grottenverwaltung" denoting the labelling system of Cave Commission.

3 The currency of the time was Gulden and Kreuzer, the " $f$ " or " $f$ " stands for the French translation of "Gulden", i.e. "Florin”.

\section{No. 747 An die löbliche Grottenverwaltungs=Commission in Adelsberg}

Note!

In Folge verehrter Note von $10^{\text {ten }}$ d. M. Zahl 37 werden dem Bergmann Valentin Tracha 50 Ct. ${ }^{1}$ Sprengpulver aus dem k. k. Zeugamte hier verabfolgt und der Betrag dafür à $20 \mathrm{Kr}$. per Pfund einsweilen mit 16 f. $40 \mathrm{Kr}^{2}$ zu Last der löblichen Verwaltungs Commission passiv in Rechnung vorgeschrieben.

Kais. Königl. Bergamt Idria am 11 Juli 1833

Prettmann Bergrath

[Reading of name not entirely certain, but same as in Note 429]

1 (funtov) (Pfund, pound) [0,56 kg]

2 This bill calculates that 1 Gulden had 60 Kreuzer! 


\section{No. 986. Vom K. K. Bergamte in Idria}

An

Die Löbliche Grotten Verwaltung in Adelsberg

[Text verso:]

\section{Löbliches k.k. Bergamt!}

Laut übergebener Note von der Adelsberger=Grottenverwaltung vom $5^{\text {ten }} 7^{\text {ber }}$ [i.e. September] 1.F. No. 52 angeführten Beschwerden und bezweifelnde Richtigkeit der vorgelegten Mappe, und nicht gemess [i.e. gemäß] angestellten Durchschlag füllt [i.e. fühlt] sich gefertigter [i.e. Gefertigter or der Unterzeichnende: the signer] keiner Verantwortung ausgesetzt zu sein. Indem kein Vorzeicher [i.e. Vorzeichner?] oder Markscheid(er) für einzelnde [i.e. einzelne] kleine Diverenzen [i.e. Differenzen] gutsteh(e)n kan(n), bey einer einfachen Aufnahme, befordert wie diese, da früher auf diesen Durchschlag gar nicht zu vermuthen, vill [i.e. viel] weniger die Genauigkeit der Figure [i.e. Abbildungen] am Ende dieser beiden Grotten zubeowachten [i.e. zu beobachten] und nur die von Urbas aufgenommene Figur an der Karte getragen. Was aber gehorsamster bei seinen [i.e. seinem] letzten Grottenbesuch entnehmen kon(n)te, dass die Gestallt oder Figur dieser beiden Grotten vermög [=möglicherweise?] der Karte etwas verschoben erscheint, so kan(n) es daher die angegebene Strecke um etwas verlängern, aber keineswegs das Zusammenkom(m)en zu bezweifeln. Und würde bei beowachtung der Karte an die nächsten Punkte, schon leicht einen näheren Aufschluss von der Zusammenkunft haben. Allein durch die teuschung des gehör, und des gegenwärtigen Ansitzen des Durchschlags kan(n) sich durch die schiefe Richtung (die Entfernung) wieder etwas vermehren jedoch $\operatorname{kan}(\mathrm{n})$ auch bei diesen vorbrechen die Löcherung [i.e. der Durchschlag] geschehen, wie es in beigeschlossener Croquis gefälligst zu ersehen ist.

Hinsichtlich der genauen Streckenangaben, währe es dem Löbl. k. k. Bergamte einzurathen die Kontrolle dieser Züge vorzuschlagen, dan(n) aber die genaue Stund anzugeben und mit den Arbeitern ein Geding oder Akort abzuschliessen, welches sich bei grösserer anstrengung auf $50 \mathrm{fl}$. pr. Kl(a)ft(e)r. berechnet, und dabei die Aufsicht in erspahrung [i.e. Ersparung] gebracht werden würde,

Idria den $8^{\text {te }} 7^{\text {ber }}$ [i.e. September] 1833

Johann Fercher, Idria

Remark: Note 57 der Grottenverwaltung is written on the frontpage of note 986 from the K.K. Bergamt of Idria

\section{No. 57, G.V.}

Dem k.k. Herren Kreisingenieur als Grottenverwaltungsmitgliede zur unumwundenen Aeusserung wieviel die Bergarbeiter im kubischen Masse in der Grotte ausgebrochen haben und wieviel ein Arbeiter in einer Tagschichte ausbrechen könne.

Grottenverwaltung Adelsberg den $318^{\text {ber }}$ (Oktober) 1833

\section{Lenertz}

[Reading of signature not entirely certain] 